\title{
“Don't Think But Look:” Using Wittgenstein's Notion of Family Resemblances to Look at Genocide
}

James J. Snow

Loyola University Maryland

Follow this and additional works at: https://digitalcommons.usf.edu/gsp

\section{Recommended Citation}

Snow, James J. (2016) "'Don't Think But Look:" Using Wittgenstein's Notion of Family Resemblances to Look at Genocide," Genocide Studies and Prevention: An International Journal: Vol. 9: Iss. 3: 154-173. DOI:

http://dx.doi.org/10.5038/1911-9933.9.3.1308

Available at: https://digitalcommons.usf.edu/gsp/vol9/iss3/12

This Articles is brought to you for free and open access by the Open Access Journals at Digital Commons @ University of South Florida. It has been accepted for inclusion in Genocide Studies and Prevention: An International Journal by an authorized editor of Digital Commons @ University of South Florida. For more information, please contact digitalcommons@usf.edu. 


\section{“Don't Think But Look:” Using Wittgenstein's Notion of Family Resemblances to Look at Genocide}

\section{Acknowledgements}

I wish to thank two anonymous peer-reviewers for their comments and suggestions. I have also benefited immeasurably from my many conversations on this topic with Professor Dale Snow. 


\title{
“Don't Think But Look:” Using Wittgenstein's Notion of Family Resemblances \\ to Look at Genocide
}

\author{
James J. Snow \\ Loyola University Maryland \\ Baltimore, MD, USA
}

\begin{abstract}
This article contributes to the ongoing and growing scholarly conversation concerning how best to define the term "genocide" following Raphael Lemkin's coining of the term in 1944. The article first shows that the Convention definition ratified in Paris in 1948 was intended solely for juridical purposes and does not reflect Lemkin's deeper understanding of genocide. It then surveys a range of scholarship after Lemkin that argues for alternative definitions of term or even calls for jettisoning the term altogether. While it is acknowledged that a clear definition is imperative in a juridical context, it is argued that there are problems and even dangers in demanding definitional precision. For purposes of coming to terms with the multidimensionality and complexities of genocidal events or the genocidal process, Wittgenstein's notion of family resemblance provides an alternative way of seeing genocide that avoids the dangers of definition.
\end{abstract}

Keywords: genocide, Lemkin, definition, Wittgenstein

\section{Introduction}

A great deal of scholarly attention is devoted to the issue of how best to define the term genocide. The term was coined and defined by Raphael Lemkin in 1944, and the definition finally adopted at the U.N. Convention on 9 December 1948 reads as follows:

In the present Convention, genocide means any of the following acts committed with intent to destroy, in whole or in part, a national, ethnical, racial, or religious group, as such:

(a) Killing members of the group;

(b) Causing serious bodily or mental harm to members of the group;

(c) Deliberately inflicting on the group conditions of life calculated to bring about its

physical destruction in whole or in part;

(d) Imposing measures intended to prevent births within the group;

(e) Forcibly transferring children of the group to another group. ${ }^{1}$

As we will see in the next section, this definition was intended solely for purposes of international law. And there are numerous critics of this definition; critics of the Convention definition fall into one of four camps. Some claim there are problems with the term as a juridical concept; it is notoriously difficult to establish intent, and the Convention definition specifies only five groups. Juridical problems notwithstanding, other argue that for purposes of prevention, we need to see genocide as a process rather than as an event and revise the definition accordingly. Still others claim the term, or more precisely the Convention definition of the term, does not facilitate a deeper understanding of the complexities or even chaos that characterize genocides. Still others advocate jettisoning the term altogether; scholars in this camp have offered any number of alternative terms and phrases meant to capture the depth and magnitude of genocidal violence.

This paper begins with a brief overview of how Lemkin himself intended and understood the term genocide as it appears in the Convention definition in contrast to his historical understanding of genocide and shows that his definition adopted in 1948 as a legal concept should not be conflated with his historical understanding of genocide. We will then evaluate the arguments of critics who wish to amend, correct, or even replace Lemkin's term. We will see that criticisms of the Convention definition along with calls for an improved or alternative definition share an all-toofamiliar received understanding of definition itself. This received conception of definition goes as far back as Plato. Rather than having recourse to alternative definitions of genocide or inventing a

1 "Convention on the Prevention and Punishment of the Crime of Genocide," https://treaties.un.org/doc/Publication/ UNTS/Volume\%2078/volume-78-I-1021-English.pdf (accessed 31 January 2016).

James J. Snow, "'Don't Think But Look': Using Wittgenstein's Notion of Family Resemblances to Look at Genocide" Genocide Studies and Prevention 9, 3 (2016): 154-173. @2016 Genocide Studies and Prevention.

http://dx.doi.org/10.5038/1911-9933.9.3.1308 
new term, the argument presented here shows that Wittgenstein's notion of family resemblances provides an alternative and effective way of looking at genocide.

\section{Defining Genocide}

Lemkin's Term

Genocide scholars do recognize an immeasurable debt to Raphael Lemkin for coining the term genocide-the word derives from the Greek word genos, or people, and the Latin cide, to kill-as well as his tireless efforts to make genocide a crime under international law. Passages throughout the published and unpublished writings make it clear that he considered it his vocation or métier to criminalize genocide. In an article published in the American Journal of International Law Lemkin makes this clear when he writes, "The realities of European life in the years 1933-45 call for the creation of such a term and for the formulation of a legal concept of destruction of human groups." ${ }^{2}$ He writes in his never completed autobiography Totally Unofficial:

Thus my basic mission in life was formulated: to create a law among nations to protect national, racial, and religious groups from destruction. The need for the innocent to be protected set off a chain reaction in my mind. It followed me all my life. Once I conceived of the destruction of groups as a crime, I could not rest quietly. Neither could I stop thinking about it. When I later coined the word "genocide," I found too an expression for my own use, but at the same time I was prepared to work more for the actual transformation of this word into the subject of an international treaty. ${ }^{3}$

A few pages later he continues:

Now was the time to outlaw the destruction of national, racial, and religious groups. I thought that the crime was so big that nothing less than declaring it an international offense would be adequate, and that it should be done by international treaty or convention. ${ }^{4}$

Not always fully recognized or appreciated in the scholarship is the fact that as an intellectual and scholar, Lemkin had a far richer understanding of genocide and the history of genocide than is suggested by the 1948 Convention definition. It is clear when looking at his other writings including unpublished material that he recognized the idea of genocide, even before being named and defined, was far more complex and multidimensional than the Convention definition might suggest. He recognized that genocide is as old as human history and a ubiquitous feature of human history, and not essentially tied to the logic of modernity, although he clearly saw the Holocaust as ushering in new aspects of genocide. He recognized that it involves far more than the mass murder of human beings. He recognized that genocides look different at different times depending on the contingencies of history.

Here is not the place to provide a detailed account of the development of Lemkin's understanding of genocidal violence. ${ }^{5}$ Still, we must recognize, if however briefly, that there are passages in his

\footnotetext{
${ }^{2}$ Lemkin, Raphael. 1947. "Genocide as a Crime under International Law." The American Journal of International Law Vol. 41, No. 1, 146.

${ }^{3}$ Lemkin, Raphael. 2013. Totally Unofficial: The Autobiography of Raphael Lemkin. Translated by Donna-Lee Frieze. New Haven: Yale University Press, 2.

${ }^{4}$ Ibid, 22.

${ }^{5}$ There is a growing and promising body of scholarship devoted to Lemkin and his understanding of genocide. See: Moses, A. Dirk. 2010. "Raphael Lemkin, Culture, and the Concept of Genocide. In The Oxford Handbook of Genocide Studies. Edited by Donald Bloxham and A. Dirk Moses, pages 19- 41. Oxford: Oxford University Press; Butcher, Thomas A. 2013. "A 'Synchronized Attack': On Raphael Lemkin's Holistic Conception of Genocide," Journal of Genocide Research Vol. 15, No. 3, 25-271; Irvin-Erickson, Douglas. 2013. "A Genocide, the Family of Mind, and the Romantic Signature of Raphael Lemkin," Journal of Genocide Research Vol.15, No. 3, 273-296; Siegelberg, Mira L. 2013. "Unofficial Men, Efficient Civil Servants: Raphael Lemkin in the History of International Law," Journal of Genocide Research Vol. 15, No. 3, 297-316; Earl, Hilary. 2013. "Prosecuting Genocide before the Genocide Convention: Raphael Lemkin and the Nuremberg Trials, 19451949." Journal of Genocide Research Vol. 15, No. 3, 317-337.
} 
published and unpublished writings that document a much subtler and nuanced understanding of genocidal violence than is evident in the Convention definition. His richly historical understanding of genocide is evident in an article published in the Christian Science Monitor in 1948:

The destruction of Carthage, the destruction of the Albigenses and Waldenses, the Crusades, the march of the Teutonic Knights, the destruction of the Christians under the Ottoman Empire, the massacres of the Herero in Africa, the extermination of the Armenians, the slaughter of the Christian Assyrians in Iraq in 1933, the destruction of the Maronites, the pogroms of Jews in Tsarist Russia and Romania - all these are classical cases. ${ }^{6}$

And in an undated and unpublished manuscript he refers to genocide as being "as old as history," although it is "repeating itself with an increasing intensity in our time."7

Moreover, Lemkin's more inclusive historical understanding of genocide also meant that he distinguished different types of genocide based on the perpetrators' intentions and purposes: he recognized that some genocides were intended to totally destroy a group; others were intended to destroy a culture through assimilation and other measures; third, some genocides seek to annihilate both members of the group and destroy the culture as well. ${ }^{8}$ An example of the second type would be the genocidal rape camps in Bosnia where women were forced to bear children who bore the ethnicity of perpetrators. An example of the third type would be the destruction of Armenian architecture by the Turks well after the killing and diaspora.

Clearly, the enduring legacy of Raphael Lemkin is that of Lemkin the jurist who framed the Convention definition, not Lemkin the scholar. This is likely best explained by the urgency he felt about proscribing genocide at the level of international law. Although he was enough of a realist to recognize that an international law proscribing genocide would not end genocide, he felt a real resolve to make it law while the memories of the Armenian genocide and the Holocaust were vivid in our memory. In a memorandum he writes about the need for ratification without delay: "It is easier to ratify a treaty of this kind while the memory of recent cases of genocide is still In [sic] our minds." 9

Do We Need a New Definition? Do We Need a Definition at All?

That we need a definition is taken almost as a given and the importance of a clear definition is often stressed in the literature. Totten and Parsons in their introduction to the fourth edition of Centuries of Genocide, stress the importance of clear definitions, albeit within the context of teaching about genocide. In a section entitled "More specifics vis-à-vis teaching and learning about genocide," they claim this: "First, it is absolutely essential to help students understand the difference between crimes against humanity, war crimes, ethnic cleansing, and genocide. A key way to do that is to provide them with a solid definition of each..."10 Totten and Parsons, and a host of others see a solid definition as central to our understanding of genocide. George Andreopoulos, in his introduction to Genocide: Conceptual and Historical Dimensions, makes perhaps the strongest claim for the importance of a sound definition. According to Andreopoulos:

The quest for a comprehensive definition would enable us first to map out the area within which the concept is to operate; an analytically rigorous definition could then be developed which would avoid conceptual overstretch. Because the concept refers to a social process, a

\footnotetext{
${ }^{6}$ Lemkin, Raphael. 1947. “War against Genocide.” Christian Science Monitor, 20.

${ }^{7}$ Lemkin, Raphael. Undated. "Memorandum on the necessity for the urgent ratification of the Genocide Convention." Raphael Lemkin Collection; P-154, box 6, folder 2. American Jewish Historical Society, New York and Boston.

${ }^{8}$ Feierstein, Daniel. 2014. Genocide as Social Practice: Reorganizing Society under the Nazis and Argentina's Military Juntas. Translated by Douglas Andrew Town. New Brunswick: Rutgers University Press, 40.

${ }^{9}$ Lemkin, Raphael. Undated. "Memorandum on the necessity for the urgent ratification of the Genocide Convention," undated, Raphael Lemkin Collection; P-154; box 6; folder 2; American Jewish Historical Society, New York, NY, and Boston, MA.

${ }^{10}$ Totten, Samuel and William S. Parsons, editors. 2013. Centuries of Genocide: Essays and Eyewitness Accounts Fourth Edition. New York: Routledge, 11.
} 
good definition has a critical functional value: to assist in the detection of early signs of an impending crisis and, provided the appropriate mechanisms are in place, devise preventive measures. Thus a good definition can be instrumental in the creation of an early warning system for the detection of genocide-prone situations. Finally, a proper conceptual framework should be able to explain nonevents: It should provide insights into why genocide-prone situations did not develop into full-scale genocides, and why societies that had that had witnessed large-scale genocidal massacres in the past managed to achieve relative stability without any structural changes in the perpetrator regime. ${ }^{11}$

Andreopoulos devotes nearly half of his book to articles that focus on what he calls "the conceptual dimensions of genocide."

Irving Louis Horowitz similarly devotes the first chapter of Taking Lives to the importance of a definition while delineating the problems surrounding a definition of the term. ${ }^{12}$ According to Horowitz, "formal definitions are either too broad to invite action or too narrow to require any [and] political definitions invariably mean what other nations do to subject populations, never what one's own does to its subjects or citizens." 13 The myriad of problems with defining genocide that Horowitz discusses notwithstanding, he still stresses the importance of a "multidimensional definition of genocide."14

\section{Proposed New Definitions}

That we need not only a definition but a new definition is suggested by the fact that there is so much scholarship devoted to either redefining Lemkin's term, replacing it with a better term, or jettisoning the term altogether.

Working within the juridical framework, Larry May has recently addressed deficiencies in the Convention definition and the International Criminal Court's Rome Statute of 1998, and made specific proposed changes. ${ }^{15}$ May focuses in particular on how best to conceive of groups and group identification given that both the Convention definition and the Rome Statute define genocide as a crime perpetrated against groups. May characterizes groups as follows: "Metaphysically the identity conditions of a group are: (1) individual human persons, (2) related to each other by organizational structure, solidarity, or common interests, and (3) identifiable, to the members, and to those who observe the members, by characteristic features." 16 It is the third condition, what he calls the "publicity condition" that is important in the context of defining genocide.

One of the major strengths of May's conceptualization of groups he mentions specifically: "the number of groups that would be officially recognized as the potential objects of genocide would increase from the current four: racial, religious, ethnic, and national groups." 17 A related strength, and one not specifically discussed by May, but still important, is this: it is easy to imagine an event in the future that might well qualify as a case of genocide but not involve one of the four identified groups, or a group we can at this historical moment not easily imagine as a victim group. May's analysis enables us to recognize genocidal violence against a group or groups for which there is no historical precedent. ${ }^{18}$

\footnotetext{
${ }^{11}$ Andreopoulos, George J. 1997. "Introduction: The Calculus of Genocide.” In Genocide: Conceptual and Historical Dimensions. Edited by George Andreopoulos. Philadelphia: University of Pennsylvania Press, 3-4.

${ }^{12}$ Irving Louis Horowitz is right, in my view, to point out that understanding and defining genocide is made especially difficult owing to the fact that it belies Western conceptions of law and morals which emphasize the culpability of individual agents and not groups: Horowitz, Irving Louis. 2002. Taking Lives: Genocide and State Power Fifth edition. New Brunswick, NJ: Transaction Publishers.

${ }^{13}$ Horowitz, Irving Louis. 2002. Taking Lives: Genocide and State Power Fifth edition. New Brunswick, NJ: Transaction Publishers, 14

${ }^{14} \mathrm{Ibid}, 27$.

${ }^{15}$ May, Larry. 2011. Genocide: A Normative Account. Cambridge: Cambridge University Press.

${ }^{16} \mathrm{Ibid}, 50$.

${ }^{17} \mathrm{Ibid}, 50$.

${ }^{18}$ A number of scholars have focused attention on how we should understand the notion of groups in the Convention definition, which provides insight as to why Lemkin himself saw groups as substantial entities. See: May, Genocide: A
} 
Still, May is working within the juridical framework. His focus is "in solving the definitional problem that has so vexed tribunals, convention drafters, courts, and international commission members for many years."19 But we need also to confront the definitional issues outside of the juridical context in our attempts to understand genocide.

Outside the juridical context, there is a spectrum of approaches to defining genocide. There are those such as Yehuda Bauer, ${ }^{20}$ Steven T. Katz, ${ }^{21}$ and even Irving Horowitz ${ }^{22}$ who want to privilege the Holocaust as a unique historical event, fundamentally different than other cases of mass brutality, and define genocide accordingly. ${ }^{23}$ At the other end of the spectrum are those such as Israel Charny who opt for a much broader definition: Charny argues for what he calls a "generic definition of genocide." In his view:

What is needed...is a generic definition of genocide that does not exclude or commit to indifference any case of mass murder of any human beings, of whatever racial, national, ethnic, biological, cultural, religious, and political definitions, or of totally mixed groupings of any and all of the above. I propose that whenever large numbers of unarmed human beings are put to death at the hands of their fellow human beings, we are talking about genocide. $^{24}$

Others frame a definition explicitly in terms of necessary conditions, i.e. in terms of what must be the case for an event to qualify as a case of genocide. Inga Clendinnen, for example, has claimed that "to take murder out of genocide is to render it vacuous" a claim contested by Raimond Gaita. ${ }^{25}$ Even an expansive definition matrix such as the one proposed by Charny, focuses on killing as a necessary condition. Much of the scholarship that focuses on a traditional definition will cast intent as a necessary condition for an event to be considered genocide. The Convention definition uses the language of intent to destroy. Michael Ignatieff, in a lecture in honour of Lemkin, refers to the Holocaust as "an ideological desire to wipe a people from the face of the earth, and to grind salt into the earth, so that they would never arise and grow again." Genocide, he continues, "has no clear meaning whatsoever unless the word can be connected to a clear intention to exterminate a human group in whole or in part."26

Claudia Card offers an alternative conceptualization of genocide by focusing on what she terms social death. She claims, "the intentional production of social death in a people or community is the central evil of genocide." ${ }^{27}$ Mohammed Abed similarly claims "social death is the harm that distinguishes genocide from other forms of political violence." ${ }^{28}$ For Card and Abed, what

Normative Account; Boghossian, Paul. 2010a. "The Concept of Genocide." Journal of Genocide Research Vol. 12, No. 1-2, 6980; Irvin-Erickson, "A Genocide, the Family of Mind and the Romantic Signature of Raphael Lemkin"; Moses, "Raphael Lemkin, Culture, and the Concept of Genocide".

${ }^{19}$ May, Genocide, 58.

${ }^{20}$ Bauer, Yehuda. 1984. "The Place of the Holocaust in Contemporary History." Studies in Contemporary Jewry Vol. 1, No. 3, 201-224.

${ }^{21}$ Katz, Steven T. 1981. “The 'Unique' Intentionality of the Holocaust.” Modern Judaism Vol. 1, No. 2, 161-183; Katz, Steven T. 1994. The Holocaust in Historical Context: Volume I: The Holocaust and Mass Death Before the Modern Age. New York: Oxford University Press.

${ }^{22}$ Horowitz, Taking Lives.

${ }^{23}$ There is a growing trend in the scholarship to attempt integrating Holocaust Studies with Genocide Studies. Universiteit van Amsterdam offered a summer seminar titled "Hidden Genocides: Overshadowed by the Holocaust in the summer of 2015; see also, Blatman, Daniel. 2015.

${ }^{24}$ Charny, Israel. 1994. "Toward a Generic Definition of Genocide." In Genocide: Conceptual and Historical Dimension. Edited by George Andreopoulos. Philadelphia: University of Pennsylvania Press, 74.

${ }^{25}$ Clendinnen, Inga. 2003. The Australian's Review of Books. Quoted in Gaita, Raimond. 2005. “Refocusing Genocide.” In Genocide and Human Rights: A Philosophical Guide. Edited by John K. Roth. New York: Palgrave, 156.

${ }^{26}$ Ignatieff, Michael. 2000. "The Legacy of Raphael Lemkin." Speech delivered at the United States Holocaust Memorial Museum. http://www.ushmm.org/confront-genocide/speakers-and-events/all-speakers-and-events/the-legacy-of-raphaellemkin (accessed 16 December 2015).

${ }^{27}$ Card, Claudia. 2010. Confronting Evils: Terrorism, Torture, Genocide Cambridge: Cambridge University Press, 237.

${ }^{28}$ Abed, Mohammed. 2006. "Clarifying the Concept of Genocide." Metaphilosophy Vol. 37, No. 3-4, 308-330. 
gives meaning to our lives are relationships, relationships that can be personal or institutionally mediated, contemporary or intergenerational; and while a life deprived of social vitality is not necessarily meaningless (here Card cites spiritual vitality), still she claims "loss of social vitality is a profound loss." ${ }^{29}$ Moreover, she claims, "putting social death at the center of genocide takes the focus off body counts, individual careers cut short, and mourners. It puts the focus instead on relationships, connections, and foundational institutions that create community and set the context that gives meaning to careers and goals, lives and deaths." ${ }^{10}$ Card's conceptualization represents a shift in focus, and it seems that she does not offer a definition per se; she does, however, state that while "social death is not necessarily genocide...genocide is social death." And it is "social death that distinguishes the evil of genocide, morally, from the evils of other mass murders." 31

Card's focus on social death certainly complements many of the testimonies of survivors as well as literature and film about life in the camps. Jean Améry's intellectual alienation in the camp, his reduction to the purely physical, and his exile from his homeland is a clear example of social death. ${ }^{32}$ Imre Kertész's narrator in Kaddish for an Unborn Child who refuses to bring a child into the post-Auschwitz world is another clear illustration of the lived experience of social death. ${ }^{33}$

Daniel Feierstein, following a relatively thorough review and criticisms of the more canonical definitions of genocide, argues in the case of modern genocides (he bases his analysis on the Holocaust and Argentina's military juntas) defines genocide as a social practice, a technology of power that is "the execution of a large-scale and systematic plan with the intention of destroying a human group as such in whole or in part," as a way of reorganizing society. ${ }^{34}$

Those writing with a focus on preventing genocide have begun focusing on reconceptualizing genocide as a process. Gregory Stanton has focused our attention on genocide as a process by identifying 10 distinct stages. ${ }^{35}$ The central argument of the 2000 African Union Report, The Preventable Genocide, is that the Rwandan genocide can be traced back 150 years to Belgian colonialism and the role of the Catholic Church. ${ }^{36}$ Sheri Rosenberg, like Stanton, focuses on prevention which, in her view, is greatly facilitated by seeing genocide as a process and not an event. She argues for what she calls genocide by attrition, a type of process-based view. As she explains, we should be mindful "of the fact that genocide is a fluid and complex social phenomenon, not a static term." 37 This represents a promising new direction in the field of genocide studies and one that complements the approach I will argue for later in this paper.

Still others argue there are fundamental problems with the very concept of genocide. Rather than focusing on the shortcomings of particular definitions, David Moshman directs our attention to problems inherent in the very notion of conceptualization as it relates to the concept of genocide. He demonstrates the dangers inherent in what he calls, proto-type" concepts - the Shoah is his example-where all other possible instances are judged against the proto-typical case; he argues instead for what he calls formal concepts which appeal to a set of necessary and sufficient conditions. While he vastly prefers the formal over the proto-typical, he sees dangers there as well. For Moshman, "we cannot escape the constraints inherent in conceptual thought," yet we can, he argues, "always transcend the limitations of our current concepts." ${ }^{38}$ Christian Gerlach casts a

\footnotetext{
${ }^{29}$ Card. Confronting Evils, 237.

${ }^{30} \mathrm{Ibid}, 238$.

${ }^{31}$ Ibid, 237.

${ }^{32}$ Améry, Jean. 1980. At the Mind's Limits: Contemplations by a Survivor and its Realities. Translated by Sidney Rosenfeld and Stella P. Rosenfeld. Bloomington: Indiana University Press.

${ }^{33}$ Kertész, Imre. 2004. Kaddish for an Unborn Child. Translated by Tim Wilkinson. New York: Random House.

${ }^{34}$ Feierstein. Genocide as Social Practice, 36.

${ }^{35}$ Stanton, Gregory. undated. Genocide Watch. http://www.genocidewatch.org/genocide/tenstagesofgenocide.html (accessed December 15, 2015).

${ }^{36}$ African Union. 2000. Rwanda: The Preventable Genocide. Available from: http://www.refworld.org African / docid/4d1da8752.html (accessed 16 May 2015)

${ }^{37}$ Rosenberg, Sheri P. 2012. "Genocide is a Process, Not an Event." Genocide Studies and Prevention: An International Journal. Vol. 7, No. 1, 17.

${ }^{38}$ Moshman, David. 2001. “Conceptual Constraints on Thinking about Genocide, Journal of Genocide Research. Vol. 3, 431.
} 
much wider net, seeing problems with how genocide scholarship often limits our understanding of mass violence. The main problem with the traditional framework, according to Gerlach, "is that genocide is a normative, action-oriented concept that has historically and essentially been created for political struggle not for scholarly analysis." ${ }^{39}$ He calls it a politischer Kampfbergriff and instead argues of an alternative concept, namely, "extremely violent societies," which he claims overcomes specific problems with the concept of genocide, namely: it excludes many forms of violence which have important links to genocide; traditional genocide scholarship is overly focused on the state; and it fails to sufficiently recognize the "multi-causal explanations of violence." 40

Given the fact that the term genocide has only been part of our vocabulary for just over 65 years, it is alarming that there are some who want to jettison the term altogether. Stuart Stein proposes that we jettison the term claiming that "the concept genocide cannot be rescued for use as a viable category type describing a delimited cluster of behaviours, and that assimilating yet more instances to this category achieves little more than name-calling." 41 Paul Boghossian is perhaps the most polemical in this regard. He claims unequivocally, "(a) that the concept defined by the UN Convention is deeply flawed; and (b) that there are no good remedies to these flaws." 42 More recently, Antonio Ferrara has suggested a new way of understanding mass violence and proposes using the term demographic surgery for the purpose of historical understanding. ${ }^{43}$

\section{The Danger of Definitions}

This review of proposed alternative definitions, a review that is admittedly not exhaustive but rather representative, shows recourse to a received and uncontested conception of definition that goes back at least to Socrates and Plato, and remained unchallenged until the twentieth century by Ludwig Wittgenstein. I want to briefly discuss Socrates' conception of definition followed by Wittgenstein's critique of the Socratic understanding. This will in turn allow us to see clearly dangers in attempting to define genocide in the traditional way and why Wittgenstein's notion of family resemblances is a more effective way of thinking about genocidal violence.

\section{Socrates' Demand for a Standard}

Within a juridical context a clear definition is imperative. Outside of this context, however, it is a different matter. Rather than addressing individual arguments that propose alternative definitions I wish to contest the claim that we need a definition at all. In fact, and especially in the case of genocide, there lurk dangers in demanding definitional clarity. We need to look at our received notion of definition itself for therein lies a crucial set of problems. All of the proposed definitions of genocide reviewed in the previous section share a common conception or understanding of

\footnotetext{
${ }^{39}$ Gerlach, Christian. 2006. “Extremely Violent Societies: An Alternative to the Concept of Genocide," Journal of Genocide Research. Vol. 8, 463-464.

${ }^{40} \mathrm{Ibid}, 464-465$.

${ }^{41}$ Stein, Stuart D. 2005. "Conceptions and Terms: Templates for Analysis of Holocausts and Genocides." Journal of Genocide Research, Vol. 7, 171-203.

${ }^{42}$ Boghossian, Paul. 2010b. "Response to my Critics." Journal of Genocide Research Vol. 12, No. 1-2, 109. This follows criticisms of his earlier paper. See Boghossian, "The Concept of Genocide". There are two concerns about these claims. First, it is notoriously difficult to prove a negative, e.g. that "there are no good remedies," unless the term is conceptually incoherent or self-contradictory. If this is what Boghossian is claiming, then he has failed to make the case. Alternatively, if he means to be making an a posteriori claim to the effect that to date the flaws have not been remedied, he would need to provide a survey of all attempts to redefine or re-conceptualize and this he has not done. A second worry concerns his earlier claim that "genocide is a coined technical term [which] implies that anyone using it must either use it to mean this technical concept or must explicitly supply an alternative definition. One cannot use the word 'genocide' without supplying some definition or other, because one cannot rely, as one might with a word in ordinary language, on some common understanding that we all have of that word, whether or not we are able to define it" (Boghossian, "The Concept of Genocide", 70). Yet he begins the same essay by claiming "the word 'genocide' gets a lot of use these days" (68). This suggests that the term is part of natural language. In the next section I will develop my argument to the effect that this is precisely where we should begin, with a careful mapping and analysis of how the term is used.

${ }^{43}$ Ferrara, Antonio. 2015. “Beyond Genocide and Ethnic Cleansing: A New Way to Understand Mass Violence." Journal of Genocide Research Vol. 17, 1-20.
} 
definition. In this section I will analyse our received understanding of a definition and show the dangers in applying that received understanding to the concept of genocide.

When Socrates and Euthyphro by chance meet at the King Archon's court, Socrates seems on the face of it astonished to learn that the young Euthyphro is there at the court to charge someone with murder. Socrates says to Euthyphro: "Heracles! Surely, Euthyphro, most people do not know where the right lies; for I fancy it is not everyone who can rightly do what you are doing, but only one who is already very far advanced in wisdom." ${ }^{44}$ Socrates is even more alarmed to learn that Euthyphro is prosecuting his own father. Socrates then says, "But, in the name of Zeus, Euthyphro, do you think your knowledge about divine laws and holiness and unholiness is so exact that, when the facts are as you say, you are not afraid of doing something unholy yourself in prosecuting your father for murder?" 45 With no trace of either irony or humility, Euthyphro assures Socrates that he does possess sufficient knowledge of the pious and the impious so as to be able prosecute his father. He therefore asks Euthyphro for a definition of holiness and unholiness: "What do you say is the nature of piety and impiety, both in relation to murder and to other things? Is not holiness always the same with itself in every action and, on the other hand, is not unholiness the opposite of all holiness, always the same with itself and whatever is to be unholy possessing some one characteristic quality?" 46

It is clear in the dialogue that Socrates is asking Euthyphro not just for a definition (Euthyphro offers any number of definitions), but a certain kind of definition. We know early on in the dialogue what definitions will not suffice. Euthyphro's initial answer to the question of what is holiness"well then, I say that holiness is doing what I am doing now, prosecuting the wrongdoer who commits murder or steals from the temples or does any such thing, whether he be your father, or your mother or anyone else, and not prosecuting him is unholy"47 -is rejected by Socrates as less than adequate. "Now call to mind," says Socrates, "that this is not what I asked you, to tell me one or two of the many holy acts, but to tell the essential aspect, by which all holy acts are holy." 48 Here Socrates is asking for an explanation of "the general idea." And a moment later, Socrates asks for a standard: "Tell me then what this aspect is, that I may keep my eye fixed upon it and employ it as a model and, if anything you or anyone else does agrees with it, may say that the act is holy, and if not, that it is unholy." 49

This way of characterizing a definition of a concept is later embraced by Aristotle as well. ${ }^{50}$ "Aristotle," claims Forster, "basically took over this theory from Plato, and due to the combined influence of these two great philosophers it went on to exercise a profound and lasting impact on Western thought-so that, for example, even today many philosophers and non-philosophers alike still labour under the impression that in order to have a clear understanding of a general term a person must be able to provide a definition of it." ${ }^{11}$ This is borne out when we review the scholarship on genocide.

\section{A Wittgensteinian Critique}

With Socrates' conception of an adequate definition illustrated we can now turn to Wittgenstein to see just how problematic this conception is, drawing primarily from the Philosophical Investigations, but secondarily the Cambridge Lectures: 1932-35. The Investigations is where Wittgenstein, following a discussion of language games, introduces the provocative notion of family resemblances, or

\footnotetext{
${ }^{44}$ Plato. 1966. Plato in Twelve Volumes, Volume 1. Translated by Harold North Fowler. Cambridge: Harvard University Press, $4 a-b$.

${ }^{45} \mathrm{Ibid}, 4 \mathrm{e}$.

${ }^{46}$ Ibid, 5c-d.

${ }^{47} \mathrm{Ibid}, 5 \mathrm{~d}-\mathrm{e}$.

${ }^{48} \mathrm{Ibid}, 6 \mathrm{~d}$.

${ }^{49} \mathrm{Ibid}, 6 \mathrm{e}$.

${ }^{50}$ Aristotle. 1999. The Metaphysics. Penguin Classics edition. New York: Penguin Classics.

${ }^{51}$ Forster, Michael. 2010. “Wittgenstein on Family Resemblance Concepts." In Wittgenstein's Philosophical Investigations: A Critical Guide. Edited by Arif Amhed. Cambridge: Cambridge University Press, 77.
} 
Familienähnlichkeiten. This notion of family resemblances starkly contrasts with what Socrates demands of his interlocutors.

In a famous passage, Wittgenstein introduces a list, not meant to be exhaustive, of examples of language-games for us to consider. Here is Wittgenstein's list:

"Giving orders, and acting on them-

Describing an object by its appearance, or by its measurements-

Constructing an object from a description (a drawing) -

Reporting an event-

Speculating about the event-

Forming and testing a hypothesis-

Presenting the results of an experiment in tables and diagrams-

Making up a story; and reading one-

Acting in a play-

Singing rounds-

Guessing riddles-

Cracking a joke; telling one-

Solving a problem in applied arithmetic-

Translating from one language into another-

Requesting, thanking, cursing, greeting, praying." 52

Not only is the list not exhaustive, it is likewise not fixed: "This diversity is not something fixed, given once and for all; but new types of language, new language games, as we may say, come into existence, and others become obsolete and get forgotten." 53

How are we to make sense of language-games? This question is complicated by the fact, as indicated above, that language games are multifarious and not fixed; they come into existence and pass out of existence. Plato and the tradition that follows would insist on a definition of language, a common feature shared by all language games, a definition of language that transcends all examples of games, or alternatively, the uses of language. Wittgenstein anticipates this worry and casts it in the form of an objection: "For someone might object against me: 'You make things easy for yourself! You talk about all sorts of language games, but have nowhere said what is essential [Wesentliche] to a language-game, and so to language. So you let yourself off the very part of the investigation that once gave you the most headache, the part about the general form of the proposition and of language'." ${ }^{54}$

In response to this anticipated objection he replies: "I'm saying that these phenomena have no one thing in common in virtue of which we use the same word for all-but there are many different kinds of affinity [Verwandschaft] between them." ${ }^{55}$ Then at PI $\$ 66$ he uses the concept of a game to illustrate further the relationship among uses. After mentioning any number of games, e.g. board games, card games, etc. he claims that there is nothing common to all games by virtue of which we call them games. He then says to one who would insist that they must have something in common: "look and see whether there is anything common to all." ${ }^{56}$ The look and see test, Wittgenstein suggests, will reveal that there is nothing common to all but instead "a complicated network of similarities overlapping and criss-crossing: similarities in the large and in the small." 57 The expression he uses to capture this network of similarities is family resemblance. ${ }^{58} \mathrm{John}$ Wisdom reminds us in his recollection of lectures he attended and conversations he had with Wittgenstein

\footnotetext{
${ }^{52}$ Wittgenstein, Ludwig. 2009. Philosophische Untersuchungen (Philosophical Investigations). Translated by G.E.M Anscombe, P.M.S. Hacker and Joachim Schulte. Revised fourth edition. Chickchester: Wiley-Blackwell, §23.

${ }^{53} \mathrm{Ibid}, \S 23$.

${ }^{54}$ Ibid, $§ 64$.

${ }^{55}$ Ibid.

${ }^{56}$ Ibid.

${ }^{57}$ Ibid, $\$ 66$.

${ }^{58} \mathrm{Ibid}, \S 67$.
} 
between 1934 and 1937, "He said that in applying the same word to several instances we mark a family resemblance-not the possession of something in common (as all ticket holders possess something in common - a ticket which matches a ticket I may hold in hand...). And this connects to his saying: 'Don't ask for the meaning, ask for the use."'59 Even without a general definition we can still explain to someone what a game is. The author thinks that replacing a Platonic conception of essentialism with a conception of family resemblances can address a number of philosophical problems and conundrums.

First, Wittgenstein helps us to see that there are intractable problems with the essentialist model of definitions. One problem with the essentialist model of definitions is the untenable philosophical commitments it involves. When Socrates presses Euthyphro for a proper definition he is asking for the Form of holiness, anticipating Plato's theory of Forms or Ideas. In other words, he is asking for something that transcends any particular instantiation of the general concept. In fact, it presupposes an abstract general form that is not immanent but transcendent. This entails a commitment to presuppositions both metaphysical and epistemological. Metaphysically it involves a commitment to an ontological realm of Ideas or Forms that are not part of the immanent domain. Epistemologically, it makes knowledge of the transcendent realm difficult if not impossible to achieve. It is worth noting that Socrates in collaboration with his interlocutors is never able to define a concept in a way that would meet his own demands. Historically Plato sets in motion the 2500 year long philosophical project of attempting to find access to, and knowledge of, a realm that is more real and lies behind the world of mere appearance. This represents a philosophical prejudice that Wittgenstein wants to dispel as a fool's errand.

Additionally, Wittgenstein wants us to focus on the immanent domain and look carefully at how words and concepts are used by language users. If we are to take careful account-employing what I am calling the look and see test-we will begin to see that, in the words of Ambrose and McDonald, "there is nothing identifiably in common for the state of affairs for which we use a word. There are only a number of overlapping resemblances. Our concepts are enormous families with various resemblances." ${ }^{60}$

This should not, on reflection, at all surprise us. Language users inevitably use language in ways that reflect perspectives or outlooks. Within the academic community historians focus more on the particular and tell stories about unique events. Stories told about perpetrators look much different than stories told from the perspective of victims or survivors. Social scientists focus more on general trends and patterns and less on the uniqueness of genocidal events. Charny recognizes the same problem when he claims "even in a society where the scientific method is the valued and prevailing mode, definitions are subject to enormous ideological and political pressures from the societal establishments within which thinkers do the work." ${ }^{61}$ In the same article Charny outlines distinct ways in which defining the term "genocide" is politicized and rife with difficulties. Jacques Sémelin also speaks to the tangle of uses of the term including issues of memory, the urging of humanitarian action, and legal purposes. ${ }^{62}$

But our inability to arrive at a clear definition of genocide may not be cause for concern for four distinct reasons. First, and as already shown, the demand for a clear definition rests on untenable philosophical assumptions. Second, given both the perspectivism of different paradigms and the politically charged nature of the debate over defining genocide it would follow that any essentialist definition that became widely used would likely represent, not truth, but instead the hegemony of a dominant discourse; the hegemony of a dominant discourse in turn marginalizes or worse silences other voices that deserve attention and recognition. Third, if we adhere to the demand for

\footnotetext{
${ }^{59}$ Wisdom, John. 1952. “Ludwig Wittgenstein, 1934-1937." Mind Vol. 61, 259.

${ }^{60}$ Wittgenstein, Ludwig. 2001. Wittgenstein's Lectures: Cambridge, 1932-1935. Edited by Alice Ambrose and Margaret McDonald. Amherst: Prometheus, 96.

${ }^{61}$ Charny, "Towards a Generic Definition," 66.

${ }^{62}$ Sémelin, Jacques. 2012. "Around the 'G' Word: From Raphael Lemkin's Definition to Current Memorial and Academic Controversies," Genocide Studies and Prevention Vol. 7, No. 1, 24-29. I find nothing of a specific nature, at least at the theoretical level, in Wittgenstein's writings that helps us to combat the political uses of the term genocide, or language more generally. I will address this problem more fully in the conclusion.
} 
definitional precision of the type demanded by Socrates and Plato, we risk narrowing our vision in such a way that we may not enrich but rather impoverish our understanding of genocide. We risk seeing history filtered through the lens of a definition. Better to bring into our purview the many uses of the term in order to refine and deepen our understanding, in order to make us wiser. These dangers need to be explicated specifically within the context of genocide.

\section{Specific Dangers in Precisely Defining Genocide}

Any essentialist definition will serve both to include and exclude from consideration any number of events; recall that Socrates tells Euthyphro that he is looking for a precise standard by which to determine what is holy and what is not. Many scholars, as shown earlier, opt for a narrow definition of genocide, going in some cases to the extreme of saying the Holocaust or Shoah is the only case of genocide in human history. Somewhat less extreme but nevertheless worrisome is the claim made by many that the Holocaust is the prototype or paradigm case of genocide, in effect claiming that while there are genocides other than the Holocaust, in comparative scholarship, the Holocaust is the standard by which all other genocides should be compared and understood. This direction in genocide scholarship can be traced to two reasons: first are the issues of memory and the understandable desire of a people to have their suffering and the suffering of their ancestors recognised as the most egregious agony ever heaped on members of the human community; second is the need to cling to the Enlightenment desire to see progress toward a future cosmopolitan world bereft of war and genocidal violence. ${ }^{63}$ The Enlightenment narrative of progress will admit eruptions of violence but only if their occurrence is against a backdrop of progress toward peace or in Kant, perpetual peace; sustaining that narrative then requires our seeing eruptions of violence as aberrational, and much of the genocide scholarship sees individual genocides in just this way. Mark Levene, for example, uses the language of an "acute malfunction of not just particular societies but of our global community writ large." ${ }^{64}$ Horowitz is seemingly more acutely aware of the problems surrounding a definition of genocide claiming in a chapter titled, "Defining Genocide" that "a multidimensional definition of genocide, rather than a unilinear, moralistic definition painted in black and white, is the surest safeguard against impoverished analysis;" ${ }^{\prime 65}$ but he then claims at the beginning of the next chapter that "genocide must be clearly distinguished from other forms of the destruction of human beings, such as natural disasters, random killings, warfare, and symbolic or cultural assaults." ${ }^{66}$ Moshman, as discussed above, has given us good reason to avoid the prototypical approach.

There are, however, a number of additional risks in definitionally or methodologically limiting our vision, even if we adopt Moshman's formal approach of necessary and sufficient conditions. The first risk lies in hiding from view that which might well enrich and deepen our understanding of genocidal violence. We need to see and consider that which lies hidden in the immanent domain, that which lies hidden in plain sight.

A second danger in seeking and then being guided in our research by essentialist definitions of genocide is that essentialist definitions risk reification and stasis. We must seriously take into account that genocidal violence is dynamic and evolving. We may well need to describe events in the future as instances of genocidal violence that only bear a family resemblance to genocidal violence of the past and present. I would argue as of this writing the current situation in Burundi bears a striking family resemblance to the genocide in Rwanda. It would be a grave mistake, as was the case of the Rwandan genocide, to debate whether the current violence in Burundi satisfies a particular definition of genocide. It might be better to look and see the family resemblance to earlier instances of genocidal violence.

The recent scholarship on war is instructive in this regard. Following the attacks on the World Trade Center towers on 9/11, then Secretary of Defense, Donald Rumsfeld, published a piece in

\footnotetext{
${ }^{63}$ This desire is reflected in Steven Pinker's book, The Better Angels of Our Nature: Why Violence has Declined. 2012. New York: Penguin. It might also explain why the book was so well received.

${ }^{64}$ Levene, Mark. 2005. The Meaning of Genocide. London: I.B. Tauris, 37.

${ }^{65}$ Horowitz, Taking Lives, 27.

${ }^{66} \mathrm{Ibid}, 29$.
} 
The New York Times with the title, "A New Kind of War." ${ }^{67}$ The new kind of war we are told, "will be a war like none other our nation has faced." Rumsfeld then frames his discussion in terms of disassociations between past wars and this new kind of war, and speculating as to what might be the case. "This war will not necessarily be one in which we pore over military targets and mass forces to seize those targets. Instead, military force will likely be one of many tools we use to stop individuals, groups and countries that engage in terrorism." Rumsfeld says of the coming war: "it is easier to describe what lies ahead by talking about what it is not rather than what it is." In Rumsfeld's text, dissimilarities far outnumber similarities and additional similarities and dissimilarities could be adumbrated. But rather than dismiss the war on terror as it later came to be called as no war at all, or not an instance of war because it fails the definitional test of what war is in essence, would, I think, be a mistake.

A third danger, one closely related to the second danger discussed above is clearly illustrated in the case of the Rwandan genocide, a genocide that according to the International Panel appointed by the Organization of African Unity was, as the title of their report indicates, a preventable genocide. ${ }^{68}$ That report is unequivocal in its central claim that the genocide was preventable.

An unforgivable tragedy for the Tutsi of Rwanda was that the international community failed to take a single step to halt the genocide once it began, even though everyone knew it was in progress. The first tragedy, however, was the one documented in this chapter. The interpretation of the countless individual incidents recorded is surely inescapable: There were a thousand early warnings that something appalling was about to occur in Rwanda. If not a genocide, it was at least a catastrophe of so great a magnitude that it should command international intervention. As we shall see, that intervention was utterly inadequate, largely owing to the political interests of the Americans and the French. ${ }^{69}$

Moreover, and as the report also establishes, the outside world including Belgian colonialism and the Catholic Church provided the very building blocks of the Rwandan genocide.

This is a danger raised by an infantry officer of the Canadian Armed Forces who worked as a personal staff officer to Major-General Romé Dallaire in Rwanda in 1993-1994. In a reflection published by the officer in 2006, he writes:

On too many occasions, especially during the genocide in Rwanda and the [then] current genocide in Darfur, the organs of the international community have been far more focused on conducting some form of academic or legal debate over the use of the word "genocide" to describe these catastrophes than on focusing our attention and efforts toward actually doing something to stop the killing. ${ }^{70}$

As a witness to the events, Major Beardsley had no doubt that he was looking at and seeing genocide.

Finally, an essentialist definition of genocide risks becoming a Procrustean bed insofar as the definition does not allow us to see events as genocidal that do not conform to our preconceived definition of what constitutes genocide. Or, to extend the Procrustean metaphor a bit further, being guided by a clear and rigid definition of genocide raises the possibility that we (mis)shape our understanding of genocidal events to coalesce with the Platonic Form.

The various attempts to redefine genocide are not likely to be successful because the ways in which language users employ the term is multifarious and does not, and in fact cannot, I argued, be defined in terms of a common essence. "There is nothing identifiably in common for the state

\footnotetext{
${ }^{67}$ Rumsfeld, Donald H. 2001. “A New Kind of War.” New York Times, 27 September.

${ }^{68}$ African Union, Rwanda.

${ }^{69} \mathrm{Ibid}, 9,16$.

${ }^{70}$ Beardsley, Brent. 2006. "The Endless Debate over the G Word." Genocide Studies and Prevention Vol. 1, 79.
} 
of affairs for which we use a word," as we are reminded in the Cambridge Lectures. ${ }^{71}$ Following Wittgenstein, using the prism of family resemblances to look at genocide means realizing that our use of the term is not fixed, and "there are many kinds of affinity" among our uses of the term; moreover it requires that we tolerate a degree of vagueness in our use of the term.

\section{A Wittgensteinian Alternative: Genocide and Family Resemblances}

I have laid stress on Wittgenstein's anti-Platonism to show problems with defining genocide, but I have yet to explore exactly how we might approach the concept of genocide through the Wittgensteinian prism of family resemblances.

First, and as part of the linguistic turn, we would do well to begin by substituting questions, as it were. Instead of asking: "What is genocide?" we might instead ask: "How is the term 'genocide' used?"72 After we have asked the right question, the next task is to examine the various examplesand lots of them - of how the term is used - don't think but look!

We should spare no effort in cataloguing the various ways in which the word genocide is used and the all-too-numerous examples of the events and processes we label as genocides. But if we are to follow Wittgenstein and catalogue the uses of the term genocide-a formidable task indeed, and a task perhaps best left to lexicographers - we would not have accomplished enough. Surely we need to do more than collect and catalogue examples of language-use, which after all would be merely empirical and therefore of limited value if our endeavour is to understand. What, then, are we to do with our collection of examples?

The problem, and it is a considerable one, is that a description, however thorough, remains a description, although this is precisely where we begin to discover the criss-cross of patterns, the family resemblances. What is missing, or perhaps lost, is any normative dimension, any way of distinguishing between the correct and incorrect use of words. Surely in our catalogue of the uses of the term genocide we will want to claim that on many occasions the word is used correctly while at the same time and on many occasions the word is used incorrectly. But how do we distinguish the occasions of correct or incorrect uses of the word? Michael Luntley captures the heart of the problem succinctly: "If what you see is what you get, all you are going to get from an account of language use for which there is no essence is an account of how things seem. And that does not sound as if it is a philosophically interesting account of language use."73 Can there be, in Wittgenstein's view, a way of distinguishing correct and incorrect use? The short answer is "yes."

What Wittgenstein is denying, among other things, is the existence of a standard that lies outside of how a word is used. That is the heart of his rejection of Platonism. As he says elsewhere: "I can characterize my standpoint no better than by saying that it is the antithetical standpoint to the one occupied by Socrates in the Platonic dialogues." ${ }^{\prime 74}$ But this does not preclude the possibility that standards for the correct use of a term cannot be found in the uses of the term. Rather than despair over the denial of an external or transcendent standard for correct use, we should instead, claims Wittgenstein, look for the standard within our keen observations of how the term is used. The rule(s) are immanent, not transcendent. The problem then becomes one of making sense of rules that are immanent.

Luntley suggests that there might be two kinds of hidden in this regard. ${ }^{75}$ While Wittgenstein denies a metaphysical realm behind the world of appearance, he nevertheless suggests a realm of the hidden within the world of appearance. In a provocative passage at PI §129 he writes:

The aspects of things that are most important for us are hidden because of their simplicity and familiarity (my emphasis). (One is unable to notice something-because it is always

\footnotetext{
${ }^{71}$ Wittgenstein, Wittgenstein's Lectures, 96.

${ }^{72}$ Here my reading of Wittgenstein follows that of Glock: Glock, Hans-Johann. 2010. "Wittgenstein on Concepts." In Wittgenstein's Philosophical Investigations: A Critical Guide. Cambridge: Cambridge University Press, 88-108.

${ }^{73}$ Luntley, Michael. 2003. Wittgenstein: Meaning and Judgement. Malden: Blackwell, 50.

${ }^{74}$ Wittgenstein, Ludwig. 2003. The Voices of Wittgenstein: the Vienna Circle. Edited by Gordon Baker. Translated by Gordon Baker, Michael Markert, John Connolly, and Vasilis Politis. London: Routledge, 32/33.

${ }^{75}$ Luntley, Wittgenstein, 50.
} 
before one's eyes). The real foundations of their inquiry do not strike people at all. Unless that fact has at some time struck them. -And this means: we fail to be struck by what, once seen, is most striking and most powerful.

This passage reveals Wittgenstein's emphasis on seeing. Luntley is again helpful: “The aim, in removing obstacles to this hidden, is not, however, to achieve a statement of the hidden. The aim is to achieve a clear sight of this hidden - to see things aright....There is no theoretical explanation, there is only a coming to see things aright."76

A number of passages in Philosophical Investigations and elsewhere reflect Wittgenstein's emphasis on seeing, and seeing things aright. For example, at PI §130 he writes: "language-games stand there as objects of comparison, which through similarities and dissimilarities, are meant to throw light on features of our language." It is in this very activity of seeing things aright that I come to see the hidden patterns of correct and incorrect use of words. There are also passages in Wittgenstein that suggest the impossibility of giving a theoretical account of correct or incorrect use of terms: "If I have learned to carry out a particular activity in a particular room (putting the room in order, say) and I am master of this technique, it does not follow that I must be ready to describe the arrangement of the room; even if I should at once notice, and could also describe, any alteration in it."77 Similarly: "It could very well be imagined that someone knows his way around a city perfectly, i.e. would confidently find the shortest way from anyplace in it to any other, and yet would be incompetent to draw a map of the city. That as soon as he tries, he produces nothing that is not completely wrong."78

If Wittgenstein is suggesting or claiming that one can know in the sense of seeing, but is nonetheless unable to explain, how does one communicate that which she knows without being able to explain what she knows?

To answer this question we need to recall Socrates' claim that in lieu of a definition, Euthyphro is only offering examples. For Wittgenstein, and consonant with his anti-Platonism, examples are precisely where one does begin. In trying to teach one what something is, rather than offer a definition in terms of necessary and sufficient conditions, one instead shows.

From the criss-cross of family resemblances, the similarities and differences, we begin to see the normative patterns that enable us to possess a concept; the normative patterns that show us the correct and incorrect use of a word begin with the examples. In Luntley's language, the examples are the starting point, or the primitive. "To say that seeing the similarities between things is primitive is to say that the normative patterns of correct use of words emerge from the activity of seeing similarities.... The patterns of correct use are not transcendent of actual use. They are immanent."79 Then in order to show" someone what the concept of genocide is, instead of an explanation, we show by examples. Wittgenstein, in discussing games at PI §69, says this: "How would we explain to someone what a game is? I think we'd describe games to him, and we might add to the description: 'This and similar things are called games."' 80 Analogously, we might say of a word like genocide, "Here are descriptions of genocides; these and similar things are called genocides."

Does the introduction of this and similar things makes this too vague, too inexact? Wittgenstein clearly thinks not. In the same paragraph he says, "and do we know anymore about ourselves? Is it just that we can't tell others exactly what a game is? - But this is not ignorance. We don't know the boundaries because none have been drawn. To repeat, we can draw a boundary - for a special purpose. Does it take this to make the concept usable? Not at all!" 81 Two points need to be made: one is explicit; the other is more implicit, but equally important. The first point is simply

\footnotetext{
${ }^{76}$ Luntley, Wittgenstein, 51.

${ }^{77}$ Wittgenstein, Ludwig. 1981. Zettel. Edited by G.E.M Anscombe and G.H. von Wright. Translated by G.E.M. Anscombe. Oxford: Basil Blackwell, §119.

${ }^{78}$ Ibid, $§ 121$.

${ }^{79}$ Luntley, Wittgenstein, 70.

${ }^{80}$ Wittgenstein, Investigations, $\$ 68$.

${ }^{81}$ Drawing boundaries for prosecutorial purposes might be just such a case.
} 
that Wittgenstein implores us to tolerate or even embrace a lack of boundaries, a vagueness in our use of concepts. Doing so does not make a concept unusable. Second is the suggestion that as language users we are who establish boundaries; we make the rules, not arbitrarily, but in our use of language.

To begin looking at genocide using the notion of family resemblances requires that we look and see how language users use the term "genocide." This requires casting a wide net. Lemkin and others use the term to characterize events as far back as the beginnings of human history. Others such as Colin Tatz use the term when discussing the treatment of Aborigines by the Australian government throughout most of the twentieth century, a genocide of assimilation involving relatively little direct killing. We might need to examine the transfer of millions of Germans the years immediately following World War II. As R.M. Douglas observes:

The Genocide Convention...being drafted by the UN's Economic and Social Committee, assisted by a legal team, was watered down in response to U.S. pressure. Its first draft had defined "forced and systematic exile of individuals representing the culture of a group" as a form of genocide. The U.S. delegate strongly opposed this clause, pointing out that it "might be interpreted as embracing forced transfers of minority groups such as have already been carried out by members of the United Nations." The prohibition on expulsions was accordingly deleted from the draft Genocide Convention by a vote of 25 to 16 , with four abstentions. ${ }^{82}$

Charny cites the bombing of Dresden: between 1942 and 1945, 131 German cities and villages were bombed by British and American forces resulting in somewhere between 500,000 and 600,000 deaths, the majority of whom were women, and another one-fifth of whom were children. As Mary Nolan notes, "No one disputes these facts. At issue are British intentions and German memories, and properly contextualized memories. Was the air war a legitimate military strategy, pursued perhaps to excess, but effective, legal, and moral nonetheless? Or did Britain deliberately target civilians to avenge London and Coventry and break civilian morale even when it was questionable whether the German war effort was negatively affected." 83 The deliberate targeting of hundreds of thousands of unarmed civilians might indeed count as genocidal. From a Wittgensteinian perspective we would also need to explore the links and resemblances among more conventional cases of genocide and the genocides associated with colonial expansion. ${ }^{84}$ We would need to look at cases of iconoclasm such as the Taliban's attacks on the Buddhas of Bamiyan. ${ }^{85}$ By the same token, attention would also need to be focused on the destruction of sacred sites of Islam perpetrated by Salafi extremists.

As a next step, and one based on our examination of those events or processes language users name genocides, we would, following Wittgenstein, begin to see patterns, a criss-cross of similarities, or family resemblances in our uses of the term. ${ }^{86}$ At the same time we would - as historians dorecognize the uniqueness and individuality of each genocide. Normatively we would also begin to see the misuses of the term as determined by the rules established within the immanent domain of language users. The uses, and misuses, of language fall under that which is seen, and does not lend itself to theoretical explanation. ${ }^{87}$ It is in seeing patterns of use that we at the same time see the normative dimension of use and decipher the patterns of correct and incorrect use.

\footnotetext{
${ }^{82}$ Douglas, Ray M. 2012. Orderly and humane: the Expulsion of the Germans after the Second World War. New Haven: Yale University Press, 335.

${ }^{83}$ Nolan, Mary. 2005. "Air Wars, Memory War" Central European History Vol. 38, 8.

${ }^{84}$ Moses, A. Dirk and Daniel Stone, editors. 2013. Colonialism and Genocide. New York: Routledge.

${ }^{85}$ Steven Miller claims that the attacks on the two Buddhas "constitute nothing less than an instance of genocide-which turns upon political will as the will to completion", Miller, Steven. 2014. War after Death: On Violence and its Limits. New York: Fordham University Press, 31.

${ }^{86}$ This parallels Gerlach's claim, "Where many genocide scholars devote much energy to neatly distinguishing between different forms of violence, I am interested in the links between them." Gerlach, Extremely Violent Societies, 464.

${ }^{87}$ This is a notoriously difficult and enigmatic part of the Philosophical Investigations and shows among other things how radical Wittgenstein's view is. A full exegesis of his text would take us beyond the scope of this paper.
} 
This approach might well enhance our understanding by helping us-recalling an earlier cited passage from the Philosophical Investigations - to see "a complicated network of similarities overlapping and criss-crossing: similarities in the large and in the small." 88 Rather than marginalizing some discourses of genocidal violence, a Wittgenstein-inspired approach would have us look at a diverse array of events that language users describe as genocides to see that criss-cross of similarities. This is, I think, what is beginning to happen in the field of comparative genocide studies. Feierstein's previously discussed book, Genocide as Social Practice, could be read as uncovering that pattern of similarities between the Nazi annihilation of European Jews and Argentina's military juntas. Feierstein's study could then be read, not as claiming to have somehow revealed the essence of genocide, but instead as showing us a criss-cross of similarities that we might see elsewhere, perhaps in the genocidal violence of the Khmer Rouge in Cambodia. Similarly, instead of adopting the methodological isolation of genocide as an isolated and isolatable form of human destruction, one could instead, and contra Horowitz, look to war or cultural destruction to see patterns and similarities that might well enrich our understanding.

Recalling our earlier discussion of Donald Rumsfeld, we might look at the war on terror through a Wittgensteinian lens and look at the criss-crossing of patterns with other things or events we call war looking for the family resemblances between this war and other wars. And in that very examination of family resemblances we come to see more clearly the depth and complexity of this new kind of war.

So too in the case of genocide: we need to look and see how language-users use the term genocide and look closely at those violent events language users call genocide in order to see the criss-cross and patterns of those events and processes we call genocide. How perpetrators construct and frame targeted groups will vary considerably: in the case of the Armenian genocide political elites of the Ottoman Empire such as Mehmet Talât Pasha (mis)framed Armenians as armed combatants who committed treason; in Guatemala in the early 1980s genocidal violence was a way of countering la subversión of the indigenous Mayan population. By contrast, targeted groups in the case of the Cambodian genocide vary, although the various groups presented a challenge to Pol Pot's nationalist revival; as Ben Kieren has shown, these groups included Buddhist monks, ethnic minorities including the Vietnamese, Chinese, and Muslim Cham. But and at the same time Khmers themselves - the majority population - were also targeted. ${ }^{89}$ Whereas the targeted group is often a minority population as was the case with the Tutsis in Rwanda, members of majority populations are not immune to genocidal violence. Similarly, while the focus of the Holocaust was on Jew and gypsies, the targeted group also included the handicapped; also included among the targeted groups were somewhere between 3 and 4 million Germans held at Dachau and other camps; Dachau was the first German camp and was intended-along with its satellite work camps - as a camp for Germans.

We might likewise be mindful of the great diversity of the weaponry or machinery of genocidal violence. In the case of the Shoah, great emphasis has been laid on the industrial scale of the killing with the use of Zyklon B at Auschwitz, and the use of gas vans at Chelmno. This contrasts with use of machetes and other farm implements in the case of Rwanda. Also in Bangladesh, BosniaHerzegovina, and Rwanda rape became a prominent genocidal weapon.$^{90} \mathrm{I}$ have elsewhere made the case that continuing and even escalating denial of the Armenian genocide by Turkish political elites and scholars, along with the destruction of Armenian public architecture, is a genocidal weapon.

\footnotetext{
${ }^{88}$ Wittgenstein, Investigations, §66.

${ }^{89}$ Kiernan, Ben. 2008. The Pol Pot Regime: Race, Power, and Genocide under the Khmer Rouge, 1975-1979. Third edition. New Haven: Yale University Press; Kiernan, Ben. 2008. Genocide and Resistance in Southeast Asia: Documentation, Denial, and Justice in Cambodia and East Timor. New Brunswick, NJ: Transaction Publishers.

${ }^{90}$ Stiglmayer, Alexandra, editor. 1993. Mass Rape: The War against Women in Bosnia-Herzegovina. Translated by Marion Faber. Lincoln: University of Nebraska Press; Nowrojee, Binaifer. 1996. Shattered Lives: Sexual Violence during the Rwandan Genocide and its Aftermath. Human Rights Watch/Africa, Human Rights Watch Women's Rights Project, Fédération Internationale des Ligues des Droits de l'Homme, Human Rights Watch. Available from http:/www.hrw.org/reports/1996/ Rwanda.htm (accessed December 16, 2015).
} 
Since intent and intent to destroy figure so centrally in our understanding of genocidal violence, the notion of family resemblances would allow us to move beyond the legalistic concerns of establishing or failing to establish intent and ask us to look carefully at the criss-cross of patterns of intention; in other words we would look at the similarities and dissimilarities of reasons perpetrators want to destroy a targeted group. The need to recognize a variety of genocidal purposes is recognized by Chalk and Jonassohn although their list of genocidal purposes could well be expanded with the lens of family resemblances. ${ }^{91}$

This brief discussion is by no means intended as any sort of comparative analysis of the genocides discussed herein; my purpose is to instead highlight certain key differences to serve as a reminder of a sometimes high degree of difference among individual genocides which in turn suggest that in looking forward we need to be open to the possibility of new horizons of genocidal violence.

\section{Conclusion}

A number of concerns and objections might we be brought against both my reading of the later Wittgenstein, as well as my argument that using Wittgenstein's notion of family resemblances can help enrich our understanding of genocide. The former objection in part rests at least in part on the fact that the later writings are enigmatic and therefore subject to a range of interpretations; the latter objection is by no means ill-founded insofar as it raises new problems for genocide scholarship. To the first concern I would argue that my reading of Wittgenstein, more so than much of the commentary, focuses on the visual, the demand that we look and see; my emphasis on the visual is, I would argue, grounded in the text, and as I have argued, precisely what is illuminative about a Wittgenstian approach to genocide. A second and reasonable objection to the approach I have argued for is that we would risk an all-too-vague conception of genocide that would fail to sustain strong moral condemnation and effective political action. In response to the claim that it would undercut or weaken the grounds for moral condemnation, I would argue that moral condemnation does in no way require a strict and exclusionary definition of a concept. On the contrary, if we exclude by definition events or processes from our purview and subscribe to the view that genocide is, among other things, the worst of all crimes, we risk discounting the degree of moral condemnation that many events and processes demand. As I argued earlier, in a juridical context a reasonably precise definition is indicated if not required; such is not required for moral condemnation. Moreover, for purposes of understanding and attempting to lessen genocidal violence, we have only to benefit from casting a wider net. Although it is beyond the scope of this paper, I would also argue that a notion of genocide understood in terms of family resemblances could likely expedite intervention, if not by nation-states bound by international law, certainly by NGOs and a host of organizations such as Genocide Watch that are committed to anticipating genocides in the future. Finally, it might be objected that a Wittgensteinian approach to genocide would do little if anything to counter the political uses and misuses of the term. On the one hand, as we learn from Foucault's lectures at the in Collège de France 1975-1976, he argues that "in the course of the eighteenth century...historical discourse eventually became a sort of discursive weapon that could be used by all the adversaries present within the political field. ${ }^{92}$ Yet on the other hand, taking Foucault's claim to heart, we might well be able to see in the immanent domain the very rules that would help us to identify political misuses of the term.

We have good reasons not to want to see genocide. Reading the opening pages of Charlotte Delbo's Days and Memory, or Primo Levi's reflections on useless violence almost inevitably elicits a frisson of horror, as does the testimony of perpetrators, be they the words of Franz Stangl in his interviews with Gitta Sereny, or Jean Hatzfeld's interviews with perpetrators in Rwanda. So too with the reports by Fergal Keane or the photographs of James Nachtwey or Gilles Peress. Truly seeing genocide might be more than we can bear; it might amount to a horrifying look

\footnotetext{
${ }^{91}$ Chalk, Frank and Kurt Jonassohn. 1990. History and Sociology of Genocide: Analyses and Case Studies. New Haven: Yale University Press.

${ }_{92}$ Foucault, Michel. 1997. "Society Must be Defended." Lectures at the Collège de France 1975-1976. Translated by David Macey. New York: Picador.
} 
in the mirror. One way of not seeing genocidal violence is to hide it, to define it or frame it in such a way that some genocides are definitionally or methodologically dismissed and hidden. But look we must. Following Wittgenstein I have argued that we might well look for the family resemblances among those events and processes in order to discover the affinities [Verwandschaften] between and among them rather than insisting that genocidal events or processes have an essence. As hinted at earlier in this paper, I see work going on in the relatively new field of Genocide Studies as moving in that direction, but only partially. I have argued that Wittgenstein's notion of family resemblances might help us to see that which we have reason to hide.

\section{Acknowledgments}

I wish to thank two anonymous peer-reviewers for their comments and suggestions. I have also benefited immeasurably from my many conversations on this topic with Professor Dale Snow.

\section{Bibliography}

Abed, Mohammed. 2006. "Clarifying the Concept of Genocide." Metaphilosophy Vol. 37, No. 3-4: pages 308-339. http://dx.doi.org/10.1111/j.1467-9973.2006.00443.x

African Union. 2000. Rwanda: The Preventable Genocide. Available from: http://www.refworld.org/ docid/4d1da8752.html (accessed 16 May 2015).

Améry, Jean. 1980. At the Mind's Limits: Contemplations by a Survivor and its Realities. Translated by Sidney Rosenfeld and Stella P. Rosenfeld. Bloomington: Indiana U. Press.

Aristotle. 1999. The Metaphysics. Penguin Classics edition. New York: Penguin Classics.

Andreopoulos, George J. 1997. "Introduction: The Calculus of Genocide." In Genocide: Conceptual and Historical Dimensions. Edited by George Andreopoulos, pages 1-28. Philadelphia: University of Pennsylvania Press.

Bauer, Yehuda. 1984. "The Place of the Holocaust in Contemporary History." Studies in Contemporary Jewry Vol.1: pages 201-224.

Beardsley, Brent. 2006. "The Endless Debate over the G Word." Genocide Studies and Prevention Vol. 1, No. 1: pages 79-82. http://dx.doi.org/10.3138/d755-7256-325k-76w4

Bloxham, Donald. 2009. The Final Solution: A Genocide. Oxford: Oxford University Press. http://dx.doi.org/10.1093/acprof:oso/9780199550333.001.0001

Boghossian, Paul. 2010a. "The Concept of Genocide." Journal of Genocide Research Vol. 12, No. 1-2: pages 69-80. http://dx.doi.org/10.1080/14623528.2010.515402

Boghossian, Paul. 2010b. "Response to my Critics." Journal of Genocide Research Vol. 12, No. 1-2: pages 105-112. http://dx.doi.org/10.1080/14623528.2010.515407

Butcher, Thomas A. 2013. "A 'Synchronized Attack': On Raphael Lemkin's Holistic Conception of Genocide," Journal of Genocide Research Vol. 15, No. 3: pages 25-271. http://dx.doi.org/10.10 $\underline{80 / 14623528.2013 .821221}$

Card, Claudia. 2010. Confronting Evils: Terrorism, Torture, Genocide. Cambridge: Cambridge University Press. http://dx.doi.org/10.1017/CBO9780511782114

Chalk, Frank and Kurt Jonassohn. 1990. History and Sociology of Genocide: Analyses and Case Studies. New Haven: Yale University Press.

Charny, Israel. 1994. "Toward a Generic Definition of Genocide." In Genocide: Conceptual and Historical Dimension. Edited by George Andreopoulos, pages 64-94. Philadelphia: University of Pennsylvania Press.

Clendinnen, Inga. 2003. The Australian's Review of Books. Quoted in Gaita, Raimond. 2005. "Refocusing Genocide." In Genocide and Human Rights: A Philosophical Guide. Edited by John K. Roth, pages 153-166. New York: Palgrave.

Convention on the Prevention and Punishment of the Crime of Genocide. 1948. https://treaties. un.org/doc/Publication/UNTS/Volume\%2078/volume-78-I-1021-English.pdf

Delbo, Charlotte. 2001. Days and Memory. Translated by Rosette Lamont. Evanston: Marlboro Press/ Northwestern University Press

Douglas, Ray M. 2012. Orderly and Humane: the Expulsion of the Germans after the Second World War New Haven: Yale University Press. 
Earl, Hilary. 2013. "Prosecuting Genocide before the Genocide Convention: Raphael Lemkin and the Nuremberg Trials, 1945-1949." Journal of Genocide Research Vol. 15, No. 3: pages 317-337. http://dx.doi.org/10.1080/14623528.2013.821225

Feierstein, Daniel. 2014. Genocide as Social Practice: Reorganizing Society under the Nazis and Argentina's Military Juntas. Translated by Douglas Andrew Town. New Brunswick: Rutgers University Press.

Ferrara, Antonio. 2015. "Beyond Genocide and Ethnic Cleansing: A New Way to Understand Mass Violence." Journal of Genocide Research Vol. 17, No. 1: pages 1-20. http://dx.doi.org/10.1080/ 14623528.2015 .991204

Forster, Michael. 2010. "Wittgenstein on Family Resemblance Concepts." In Wittgenstein's Philosophical Investigations: A Critical Guide. Edited by Arif Amhed, pages 66-87. Cambridge: Cambridge University Press. http://dx.doi.org/10.1017/CBO9780511750939.005

Foucault, Michel. 1997. "Society Must be Defended." Lectures at the Collège de France 1975-1976. Translated by David Macey. New York: Picador.

Gaita, Raimond. 2005. "Refocusing Genocide." In Genocide and Human Rights: A Philosophical Guide. Edited by John K. Roth, pages 153-166. New York: Palgrave.

Glock, Hans-Johann. 2010. "Wittgenstein on Concepts." In Wittgenstein's Philosophical Investigations: A Critical Guide, pages 88-108. Cambridge: Cambridge University Press. http://dx.doi.org/10.1017/CBO9780511750939.006

Hatzfeld, Jean. 2008. A Time for Machetes, The Rwandan Genocide: The Killers Speak. Translated by Linda Coverdale. London: Serpent's Tail.

Horowitz, Irving Louis. 2002. Taking Lives: Genocide and State Power fifth edition. New Brunswick, NJ: Transaction Publishers.

Ignatieff, Michael. 2000. "The Legacy of Raphael Lemkin.” Speech delivered at the United States Holocaust Memorial Museum, 13 December. Available from: http://www.ushmm.org/ confront-genocide/speakers-and-events/all-speakers-and-events/the-legacy-of-raphaellemkin (accessed 24 December 2014)

Irvin-Erickson, Douglas. 2013. "A Genocide, the Family of Mind' and the Romantic Signature of Raphael Lemkin," Journal of Genocide Research Vol.15, No. 3: pages 273-296. http://dx.doi.org/10.1080/14623528.2013.821222

Katz, Steven T. 1994. The Holocaust in Historical Context: Volume I: The Holocaust and Mass Death Before the Modern Age. New York: Oxford University Press.

Katz, Steven T. 1981. "The 'Unique' Intentionality of the Holocaust." Modern Judaism Vol. 1: pages 161-183. http://dx.doi.org/10.1093/mj/1.2.161

Keane, Fergal. 1997. Season of Blood: A Rwandan Journey. London: Penguin.

Kertész, Imre. 2004. Kaddish for an Unborn Child. Translated by Tim Wilkinson. New York: Random House.

Kiernan, Ben. 2008a. The Pol Pot Regime: Race, Power, and Genocide under the Khmer Rouge, 1975-1979. Third edition. New Haven: Yale University Press.

Kiernan, Ben. 2008b. Genocide and Resistance in Southeast Asia: Documentation, Denial, and Justice in Cambodia and East Timor. New Brunswick, NJ: Transaction Publishers.

Lemkin, Raphael. 1947a. "War against Genocide." Christian Science Monitor, 20 January.

Lemkin, Raphael. 1947b. "Genocide as a Crime under International Law." The American Journal of International Law Vol. 41, No. 1: pages 145-151.

Lemkin, Raphael. Undated. “Genocide," undated, Raphael Lemkin Collection; P-154, box 6, folder 2. American Jewish Historical Society, New York and Boston.

Lemkin, Raphael. Undated. "Memorandum on the necessity for the urgent ratification of the Genocide Convention," undated, Raphael Lemkin Collection; P-154, box 6, folder 2. American Jewish Historical Society, New York and Boston.

Levene, Mark. 2005. The Meaning of Genocide. London: I.B. Tauris.

Levi, Primo. 1988. The Drowned and the Saved. Translated by Raymond Rosenthal. New York: Simon and Schuster.

Luntley, Michael. 2003. Wittgenstein: Meaning and Judgement. Malden: Blackwell. http://dx.doi. org/10.1002/9780470776223 
May, Larry. 2011. Genocide: A Normative Account. Cambridge: Cambridge University Press.

Miller, Steven. 2014. War after Death: On Violence and its Limits. New York: Fordham University Press. http://dx.doi.org/10.5422/fordham/9780823256778.001.0001

Moses, A. Dirk and Daniel Stone, editors. 2013. Colonialism and Genocide. New York: Routledge.

Moses, A. Dirk. 2010. "Raphael Lemkin, Culture, and the Concept of Genocide. In The Oxford Handbook of Genocide Studies. Edited by Donald Bloxham and A. Dirk Moses, pages 19-41. Oxford: Oxford University Press. http://dx.doi.org/10.1093/oxfordhb/9780199232116.013.0002

Nolan, Mary. 2005. "Air Wars, Memory War," Central European History Vol. 38, No. 1: pages 7-40. http://dx.doi.org/10.1163/1569161053623651

Nowrojee, Binaifer. 1996. Shattered Lives: Sexual Violence during the Rwandan Genocide and its Aftermath. Human Rights Watch/Africa, Human Rights Watch Women's Rights Project, Fédération Internationale des Ligues des Droits de l'Homme, Human Rights Watch, http:/ www.hrw.org/reports/1996/Rwanda.htm

Plato. 1966. Plato in Twelve Volumes, Volume 1. Translated by Harold North Fowler. Cambridge: Harvard University Press.

Rosenberg, Sheri P. 2012. "Genocide is a Process, Not an Event." Genocide Studies and Prevention: An International Journal. Vol. 7, No. 1: pages 16-23. http://dx.doi.org/10.3138/gsp.7.1.16

Rumsfeld, Donald H. 2001. "A New Kind of War." New York Times, 27 September.

Sémelin, Jacques. 2012. "Around the ' $G$ ' Word: From Raphael Lemkin's Definition to Current Memorial and Academic Controversies," Genocide Studies and Prevention Vol. 7, No. 1: pages 24-29. http://dx.doi.org/10.3138/gsp.7.1.24

Sereny, Gitta. 1983. Into That Darkness: An Examination of Conscience. New York: Vintage.

Siegelberg, Mira L. 2013. "Unofficial Men, Efficient Civil Servants: Raphael Lemkin in the History of International Law," Journal of Genocide Research Vol. 15, No. 3: pages 297-316. http://dx.doi.org/10.1080/14623528.2013.821224

Snow, James. 2015. "Death is not the End of Genocide: Reflections on the Genocide of the Armenians." address given at the international conference, "Surviving the Catastrophe; Commemoration of the Armenian Genocide," Katholieke Universiteit Leuven, 30 April 2015. Available from: https://www.academia.edu/12199589/Death is not the end of genocide Reflections on the genocide of the Armenians (accessed 5 November 2014)

Stanton, Gregory. Undated. Genocide Watch. http://www.genocidewatch.org/genocide/ tenstagesofgenocide.html

Stein, Stuart D. 2005. "Conceptions and Terms: Templates for Analysis of Holocausts and Genocides." Journal of Genocide Research Vol. 7, No. 2: pages 171-203. http://dx.doi. org $/ 10.1080 / 14623520500127340$

Stiglmayer, Alexandra, editor. 1993. Mass Rape: The War against Women in Bosnia-Herzegovina. Translated by Marion Faber. Lincoln: University of Nebraska Press.

Totten, Samuel and William S. Parsons, editors. 2013. Centuries of Genocide: Essays and Eyewitness Accounts Fourth Edition. New York: Routledge.

Wisdom, John. 1952. "Ludwig Wittgenstein, 1934-1937." Mind Vol. 61, No. 242: pages 258-260. http://dx.doi.org/10.1093/mind/LXI.242.258

Wittgenstein, Ludwig. 2009. Philosophische Untersuchungen (Philosophical Investigations). Translated by G.E.M Anscombe, P.M.S. Hacker and Joachim Schulte. Revised fourth edition. Chickchester: Wiley-Blackwell.

Wittgenstein, Ludwig. 2003. The Voices of Wittgenstein: the Vienna Circle. Edited by. Gordon Baker. Translated by Gordon Baker, Michael Markert, John Connolly, and Vasilis Politis. London: Routledge.

Wittgenstein, Ludwig. 2001. Wittgenstein's Lectures: Cambridge, 1932-1935. Edited by Alice Ambrose and Margaret McDonald. Amherst: Prometheus.

Wittgenstein, Ludwig. 1981. Zettel. Edited by G.E.M Anscombe and G.H. von Wright. Translated by G.E.M. Anscombe. Oxford: Basil Blackwell. 